\title{
Effects of a 5\% monosulfated glycosaminoglycan and duasorb topic solution on alkali-burned rabbit corneas
}

\section{Efeitos de uma solução tópica a $5 \%$ de glicosaminoglicanos monossulfatados e duasorb, em úlceras corneanas produzidas por álcali em coelhos}

Ivia Carmem Talieri, ${ }^{*}$ Luiz Eduardo Carvalho Buquera, ${ }^{*}$ Felipe Antônio Mendes Vicenti, ${ }^{*}$ Adriana Torrecilhas Jorge Brunelli,, Carla de Freitas Campos, ${ }^{*}$ Julieta Rodini Engrácia de Moraes, ${ }^{* *}$ José Luiz Laus*

\begin{abstract}
Topical effects of chondroitin sulfate, a monosulfated glycosaminoglycan, on the healing of alkali-burned corneas were studied. Forty albino rabbits were divided into two groups ( $\mathrm{Gl}$ and $\mathrm{Gll}, \mathrm{n}=20$ ) submitted to corneal ulceration with $3 \mathrm{M}$ sodium hydroxide $(\mathrm{NaOH})$. GI was treated with a topical solution of $5 \%$ chondroitin sulfate 4 and chondroitin sulfate 6 and Gll was treated with $0.9 \%$ physiological saline at 6 hour intervals in both cases. The rabbits were studied over a period of 60 days by biomicroscopy with a slit lamp in order to evaluate blepharospasm, blepharitis, chemosis, conjunctival congestion, ocular secretion, and corneal edema, neovascularization and macula. The fluorescein test was performed daily to monitor the evolution of the ulcers. The animals were submitted to eye enucleation for histopathology on the $1^{\text {st }}, 3^{\text {rd }}, 10^{\text {th }}, 30^{\text {th }}$ and $60^{\text {th }}$ day after ulcer induction. When compared to GII, GI showed 4 perforations. In the eyes in which no perforation occurred, no clinical or microscopic differences were observed between groups, except for ocular secretion, which persisted for a longer time in Gll animals. Except for those with perforations, the corneas tended to heal, on average, within 30 days. The results permit us to conclude that the $5 \%$ chondroitin sulfate solution, when instilled on alkali-burned rabbit corneas did not alter healing when compared to the animals treated with $0.9 \%$ physiological saline.
\end{abstract}

Keywords: alkali-burned cornea, rabbits, monosulfated glycosaminoglycan, chondroitin sulfate.

\section{Introduction}

The usual presence of alkalis in cleaning products and in construction materials contributes to the relatively frequent occurrence of chemical burns (Donzis and Mondino, 1987; Wagoner, 1997). Alkalis can rapidly penetrate the eye (Hughes, 1946; Pfister, 1983; Chung And Fagerholm, 1987; Christmas, 1991), lysing cells, denaturing collagen and hydrolyzing glycosaminoglycans of the stroma (Pfister, 1983; Christmas, 1991). Residues of the substance continue the destructive process unless they are completely removed (Hughes, 1946; Christmas, 1991). Depending on the extent of penetration, alkalis can produce ischemia and necrosis of the sclera and conjunctiva, ulcers and perforations. They may also damage lacrimal glands and ducts, predisposing to temporary or permanent keratoconjunctivitis sicca (Christmas, 1991), and the episclera, the iris, the ciliary body, trabecular network and lens epithelium (Wagoner, 1997), with consequent uveitis, glaucoma and cataract (Hughes, 1946; Stein et al., 1973; Pfister, 1983; Christmas, 1991).

Epithelial lining occurs in the quadrants where limbus stem cells are preserved (Wagoner, 1997). The evolution of the lesions produced by alkali is related, among other factors, to the extent of neovascularization. Blood cells originating from the limbus transport fibroblasts, epithelial cells (Brown et al., 1969; Pfister and Burstein, 1976) and anti-collagenase factors from serum to the cornea. Within a few hours after the lesion, polymorphonuclear cells (PMNs) appear in the conjunctiva and the sclera and rapidly penetrate the stroma (Hughes, 1946).

The recurrence of corneal ulcers and perforations is one of the major and most frequent problems in extensive burns (Brown et al., 1969). This is a consequence of collagen destruction by enzymes, collagenase in particular (Brown et al., 1969; Burns et al., 1989; Burns et al., 1990). Their genesis is due to regenerating epithelial cells (Gnädinger et al., 1969) and PMNs that invade the stroma, as well as fibroblasts (Brown et al., 1970; Henriquez et al., 1976; Pfister and Burstein, 1976; Burns et al., 1989; Burns et al., 1990).

Twenty-four hours after the burn, there is rearrangement of collagen and glycosaminoglycans, with debris absorption. Fibroblasts and keratocytes invade the cornea to form scar tissue exhibiting a low degree of organization (Chung and Fagerholm, 1987). In rabbits there is the formation of a retrocorneal membrane consisting of several layers of connective tissue which transforms into regenerated endothelium (Matsuda and Smelser, 1973).

\footnotetext{
* Depto. de Clínica e Cirurgia Veterinária, Faculdade de Ciências Agrárias e Veterinárias, UNESP, Via de acesso: Prof. Paulo Donato Castellane, Km 5 CEP 14994-800, Jaboticabal, SP. E-mail: jllaus@fcav.unesp.br

** Depto. de Patologia Veterinária, Faculdade de Ciências Agrárias e Veterinárias, UNESP, Via de acesso Prof. Paulo Donato Castellane, Km 5 CEP 14994-800, Jaboticabal, SP.
} 
Alkali-burned eyes represent a great therapeutic challenge (Burns et al., 1990; Schultz et al., 1992). Among the clinical procedures proposed thus far are copious irrigation with water immediately after the accident and instillation of atropine for the relief of ciliary spasm and for the prophylaxis of synechiae (Hughes, 1946; Donzis and Mondino, 1987; Christmas, 1991). Other substances used are acetylcysteine (Burns et al., 1989), cysteine, sodium citrate and ascorbate (Donzis and Mondino, 1987; Burns et al., 1990; Christmas, 1991; Wagoner, 1997), bmercaptometthyl tripeptide, systemic tetracycline (BURNS et al., 1990), sodium EDTA, EDTA with calcium, blood serum (Rebhun, 1981), tear substitutes, epidermal growth factor, retinoic acid, sodium hyaluronate (Wagoner, 1997), and fibronectin (Burns et al., 1990; Mori et al., 1993), in addition to systemic or topical anti-prostaglandin drugs (Christmas, 1991; Wagoner, 1997).

Surgical procedures based on re-lining with the third eyelid and conjunctival flaps are used in order to protect the cornea and to offer blood supply, respectively (Christmas, 1991).

Monosulfated glycosaminoglycans such as chondroitin sulfate 4 and chondrotin sulfate 6 stimulate collagen formation, and inhibit the classical and alternative pathway of the complement cascade in vitro, with depletion of their components and reduction of inflammation (Rashmir-Raven et al., 1992). They also inhibit collagen degradation by metalloproteinases and by serum proteinases (Burns et al., 1989; Glade, 1990; Clegg et al., 1998). The effects of these substances on indolent ulcers have been studied in dogs and horses (Miller, 1996; Wouk et al., 1998). The authors used a $5 \%$ topical solution of polysulfated glycosaminoglycans and obtained ulcer healing within one and three weeks after the trauma.

The present study was designed to investigate the effects of chondroitin sulfate 4 and chondroitin sulfate 6 diluted in duasorb and instilled in the form of a $5 \%$ solution on the healing of alkali-burned rabbit corneas.

\section{Materials and methods}

\section{Experimental Design}

The study was in accordance with the ARVO statement and with our institution for the use of animals in ophthalmic and vision research.

Forty adult male and female albino New Zealand rabbits weighing on average $3 \mathrm{~kg}$ were divided into two groups of 20 animals each called GI and GII. GI animals were used to evaluate the effects of a $5 \%$ chondroitin sulfate 4 and chondroitin sulfate 6 solution (Artroglycan Injetável 12\%: Syntex S.A., Buenos Aires, Argentina), diluted in duasorb (Lacrima: Alcon Laboratórios do Brasil Ltda, São Paulo, Brazil) and applied at six hour intervals for 60 days. Gll animals were similarly treated with a $0.9 \%$ sodium chloride solution (Solução Fisiológica: Laboratório Farmacêutico Arboreto Ltda, Juiz de Fora, Brazil).

\section{Preparation of the 5\% Chondroitin Sulfate Solution}

The literature proposes the use of a $5 \%$ polysulfated glycosaminoglycan solution for the management of corneal ulcers (Miller, 1996; Wouk et al., 1998). Following the same protocol, we mixed $5 \mathrm{ml}$ of Artroglycan Injetável 12\%â with $7 \mathrm{ml}$ of Lacrimaâ in order to obtain a $5 \%$ chondroitin sulfate 4 and chondroitin sulfate 6 solution which was stored under refrigeration at $4^{\circ} \mathrm{C}$ until the time for use.

\section{Corneal Ulcers}

The corneal ulcers were induced in a single eye using a filter paper disk (Quanty Papel de Filtro Quantitativo 9cm JP42: J. Prolab, Curitiba, Brazil) $8 \mathrm{~mm}$ in diameter soaked in an alkaline $3 \mathrm{M} \mathrm{NaOH}$ solution. The size of the ulcer and the concentration of alkali were chosen after preliminary studies to avoid rapid spontaneous healing and to avoid melting and perforation. For this procedure, the animals's cornea was desensitized with tetracaine and epinephrine eyedrops (Colírio Anestésico: Allergan Produtos Farmacêuticos Ltda, Guarulhos, Brazil). The disk was positioned on the dorsal region of the ocular globe for 30 seconds at the 10 and 2 o'clock position, with one 1/3 placed on the region of the limbus and sclera and $2 / 3$ on the cornea. The ocular surface was abundantly irrigated with physiological saline for 2 minutes immediately after burning.

\section{Clinical and Histopathological Evaluation}

Events involving chemosis, blepharitis, blepharospasm, conjunctival congestion, secretion, corneal edema, neovascularization and macula were evaluated by a qualitative and quantitative criterion as follows: (Nihil) absence of signs, $(+)$ discrete manifestation of signs, $(++)$ moderate signs, and $(+++)$ intense signs. The corneas were examined daily under a biomicroscope with a slit lamp for 60 days (Portable Slit Lamp SL-14: Kowa Company Ltda, Tokyo, Japan) and submitted to the fluorescein test (Fluoresceína Strips: Ophthalmos, São Paulo, Brazil).

For light microscopy, four animals per group were evaluated at 1, 3, 10, 30 and 60 days. Samples fixed in Bouin's solution, washed with increasing alcohol concentrations from 70 to $100 \%$ and cut into $5 \mathrm{~mm}$-thick sections were stained with hematoxylin-eosin. Events concerning the inflammatory and healing responses were studied, i.e., edema, hemorrhage, vessel neoformation and congestion, and leukocyte infiltrate.

\section{Statistical Analysis}

Clinical data were analyzed statistically by the Kruskal-Wallis test (one factor analysis of variance for nonparametric data) for comparison between groups at each time point, with the level of significance set at $5 \%$ ( $p £ 0.05)$. For this analysis, a 0 value was used for absence of signs (Nihil), 1 for mild manifestation of signs $(+), 2$ for moderate $(++)$ manifestation, and 3 for intense manifestation $(+++)$. The same criteria were applied to the ulcerations.

\section{Results}

\section{Clinical Evaluation}

Figures 1 and 2 illustrate the course of the clinical events throughout the study period. Blepharospasm, chemosis and conjunctival congestion were intense during the first days in both groups (Figs. 3A and $3 \mathrm{~B}$ ), gradually decreasing thereafter until full disappearance (Figs. 3C and 3D). Blepharitis was always mild in both groups. Mucoid secretion was more intense 


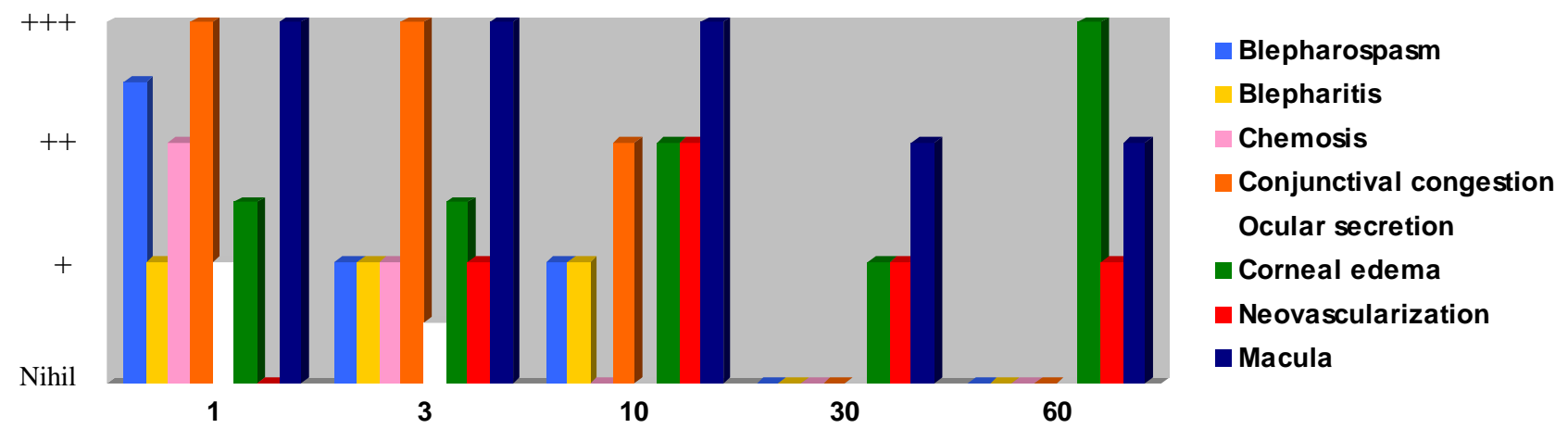

Postoperative days

Figure 1: Summary of the clinical observations from Gl divided into: (Nihil) absent; $(+)$ discrete; $(++)$ moderate and $(+++)$ intense.

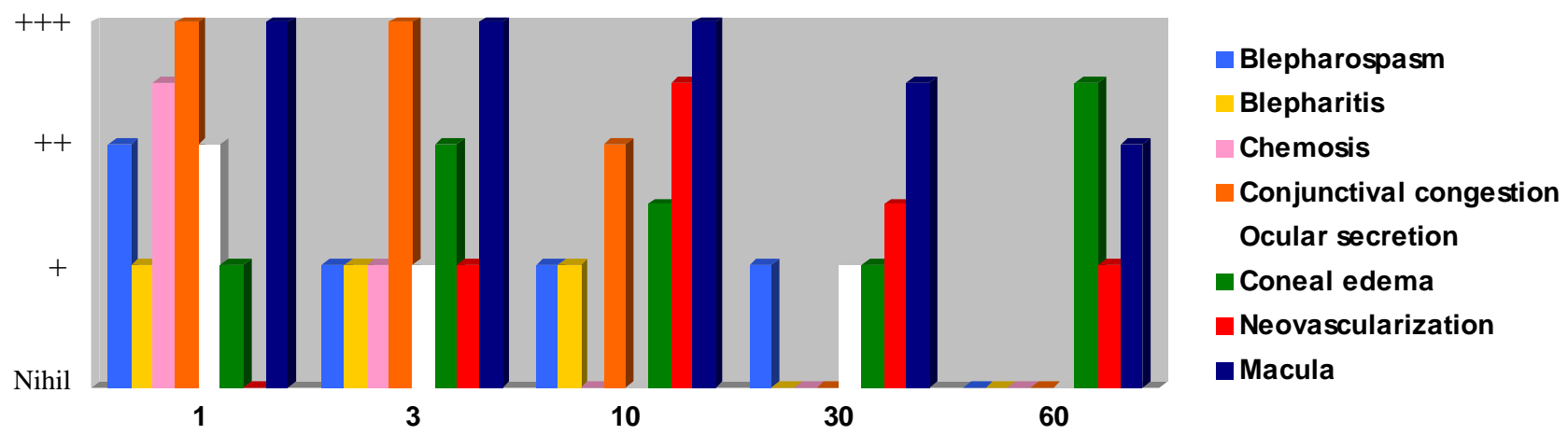

Postoperative days

Figure 2: Summary of the clinical observations from Gll divided into: (Nihil) absent; $(+)$ discrete; (++) moderate and (+++) intense.

in Gll than in GI. Edema was more pronounced in GI up to the $10^{\text {th }}$ day and was mild in both groups by the $30^{\text {th }}$ day (Fig. $3 \mathrm{C}$ ), becoming intense by the $60^{\text {th }}$ day (Fig. 3D). Starting on the $3^{\text {rd }}$ day, superficial neovessels started to invade the cornea from the ventral area and from the lateral portion on the subsequent days. By the $10^{\text {th }}$ day the corneas were intensely vascularized (Fig. 3B). The new vessels gradually elongated and became scarce by the $60^{\text {th }}$ day (Figs. $3 C$ and 3D). Macula induced by alkali burn was intense up to the $10^{\text {th }}$ day of evaluation (Fig. 3B) and became moderate by the $30^{\text {th }}$ day in both groups (Fig. 3C). Iridocyclites were visible in all animals of both groups, manifesting in the form of edema and iris congestion, hyphema (observed in one animal of each group), flare (observed in one animal of each group), and hypopyon (identified in two GII animals). The corneal ulcers exhibited variable behavior in terms of the extension of fluorescein-stained areas. Four perforations occurred in
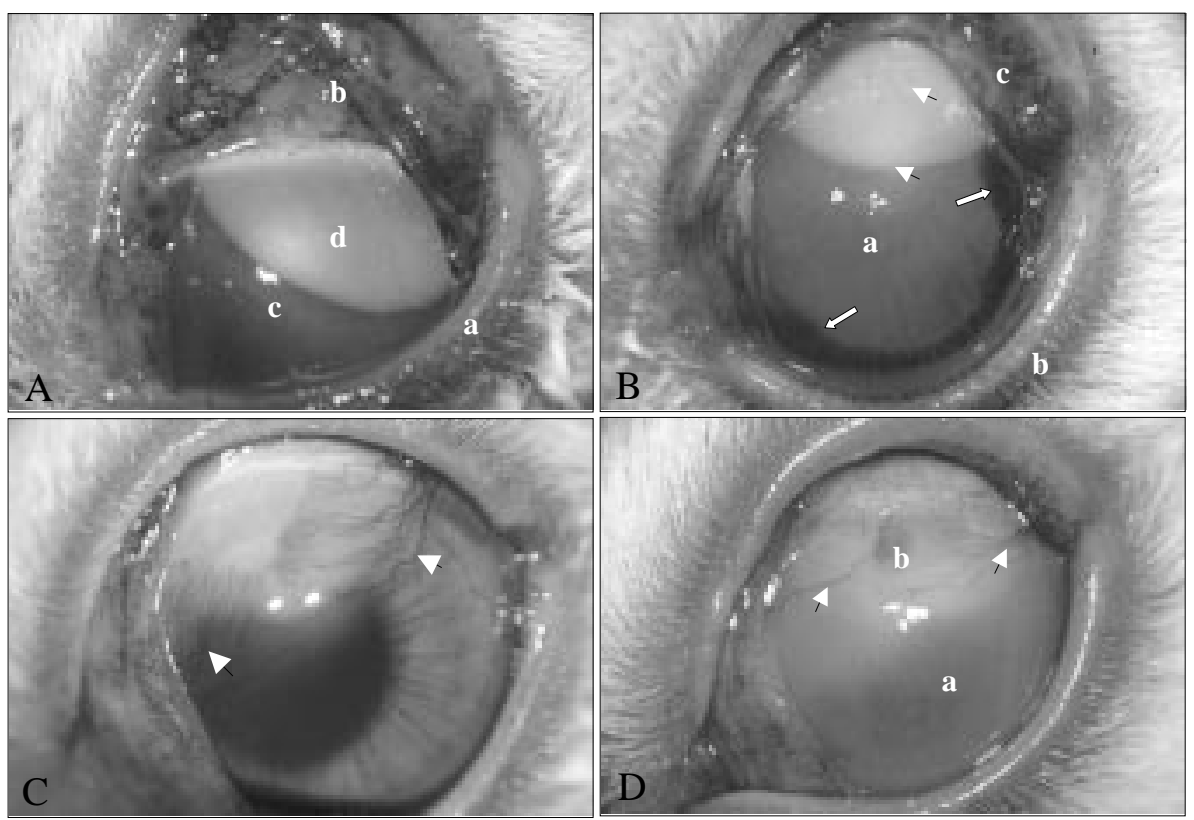

Figure 3. Photographic images of rabbit eyes submitted to the action of $3 \mathrm{M}$ sodium hydroxide. A: After 3 days of treatment with a topical $5 \%$ chondroitin sulfate solution. Observe blepharitis (a), marked chemosis, conjunctival congestion (b), corneal edema (c), and macula (d). B: After 10 days of treatment with physiological saline. Note the superficial punctiform ulcers (arrows), corneal edema (a), neovascularization (thick arrows), blepharitis (b), and conjunctival congestion (c). C: After 30 days of treatment with a topical $5 \%$ chondroitin sulfate solution. Note the reduction of corneal edema and the elongation of newly formed vessels (arrows). D: After 60 days of treatment with physiological saline. Note the reappearance of corneal edema (a), macula (b) and discrete newly formed vessels (arrows). 
GI on the $8^{\text {th }}, 12^{\text {th }}$ (two cases) and $19^{\text {th }}$ days of evaluation, respectively.

\section{Histopathologial Evaluation}

On the $1^{\text {st }}$ and $3^{\text {rd }}$ days of evaluation, the alkali-burned area of both groups presented desquamating epithelium, absence of fibrocyte nuclei and dissociation of collagen fibers, especially in the anterior and middle portions of the stroma, as well as compaction in the posterior portion (Fig. 4A). At 10 and 30 days of evaluation, the epithelium continued to be desquamating with rounded young fibrocyte nuclei in the stroma of the damaged corneal area (Fig. 4C). At 60 days, Gl still exhibited areas of desquamated epithelium and dissociation of collagen fibers. The anterior stroma was found to be disorganized near the burn (Fig. 4D).

On the $1^{\text {st }}$ and $3^{\text {rd }}$ days, the endothelium consisted of only a few cells located at the periphery of the cornea. At 10 days there was the formation of a retrocorneal membrane close to the burned conjunctiva (Fig. 4B). On the $30^{\text {th }}$ day, the corneal epithelium was found to be normal in $\mathrm{Gl}$ and hyperplastic in GII. At 60 days it exhibited few cells in both groups.

At 10 days, newly formed vessels started to invade the anterior and middle stroma of the area not burned with alkali and at 30 days they were present in larger numbers in the middle stroma and in the entire cornea (Fig. 4C).

On the $1^{\text {st }}$ and $3^{\text {rd }}$ days, the anterior chamber presented cell debris and PMNs, more intensely so in GII. However, at 10 days, it was Gl that presented more cell debris (Fig. 4B). At 30 days, cell debris were no longer present in the anterior chamber in Gll and were discretely present in Gl, disappearing by 60 days.

\section{Statistical Analysis}

Clinical signs were compared between groups at the different periods of time by the Kruskal-Wallis test. A significant difference in secretion was detected at 10 days $(p=0.0328)$ and at 30 days $(p=0.0336)$. No significant differences were detected between groups with respect to the remaining signs.

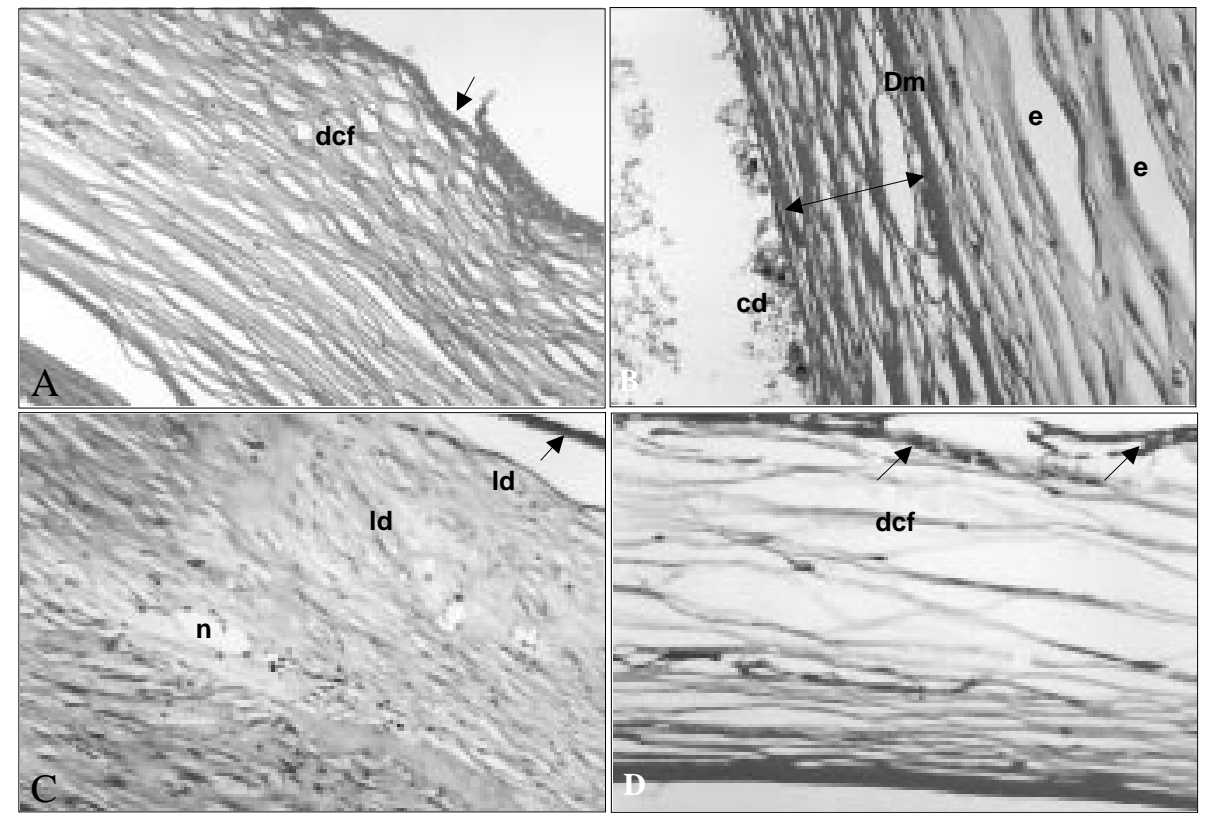

Figure 4: Photomicrographs of transverse section of rabbit corneas submitted to the action of $3 \mathrm{M}$ sodium hydroxide. A: 1 st day of treatment with a topical $5 \%$ chondroitin sulfate solution. Note the desquamating epithelium (arrow), edema with dissociation of collagen fibers (dcf) and absence of fibrocytes (HE, 20X). B: 10th day with treatment of a topical $5 \%$ chondroitin sulfate solution. Observe the edema in the middle stroma (e) with lamellar disorganization, retrocorneal membrane (double arrow) adjacent to the Descemet membrane (Dm), cell debris (cd), and inflammatory cells in the anterior chamber (HE, 40X). C: 30th day of treatment with a physiological saline. Note the partially regenerated epithelium (arrow) with few cells, lamellar disorganization (Id), edema and newly formed vessels $(n)(H E, 20 X)$. D: 60th day of treatment with a topical $5 \%$ chondroitin sulfate solution. Note the partially regenerated epithelium in the area of corneal lesion (arrows), dissociation of collagen fibers (dcf) and absence of endothelium (HE, 20X).

\section{Discussion}

Alkali burns were used to produce corneal ulcerations to be studied in terms of the effects of anticollagenolytic and healinginducing substances (Burns et al., 1990). Differences in the intensity of chemical injury resulted in varying degrees of ulceration (Henriquez et al., 1976). In the present study we standardized the use of $3 \mathrm{M}$ caustic soda in a model based on the induction of lesions including limbus areas that would permit us to study the changes occurring in the presence of stem cell destruction (Wagoner, 1997).

The injury produced by chemical burns can be permanent. Lytic enzymes originate from epithelial cells, PMNs and fibroblasts. Collagenase activity may result in inadequate collagen repletion, ulcers and subsequent perforations (Pfister and Burstein, 1976). Inhibition of the action of lytic enzymes has been the primary goal in the clinical management of alkali burns (Burns et al., 1989).

Fibroblasts actively produce collagen, thus aiding healing. Thus, the rapid action of healthy fibroblasts after an alkali burn is considered to be the primary condition for good healing repair in the maintenance of corneal integrity (Pfister and Burstein, 1976).

Taking into account the biochemical and physiological events caused by alkali burns, a combination of therapeutic approaches becomes imperative (Burns et al., 1989). Protocols that act with some success by reducing the incidence of corneal ulcers and perforations in alkali burns involve five categories of healing substances: agents that inhibit PMN migration and infiltration into the cornea, collagenase inhibitors, anti-inflammatory agents, and substances that stimulate collagen synthesis (Burns et al., 1990). 
We studied the effect of a topical $5 \%$ chondroitin sulfate solution on alkali-burned rabbit corneas because of the well known actions of glycosaminoglycans on inflammation by inhibition of the classical and alternative pathways of complement (Rashmir-Raven et al., 1992) and by reduction of prostaglandin $\mathrm{E}_{2}$ and superoxide radical synthesis (Miller, 1996; Wouk et al., 1998 ), on collagen degradation by the inhibition of metalloproteinases and serum proteinases (Burns et al., 1989; Glade, 1990; Miller, 1996; Clegg, et al., 1998; Wouk et al., 1998) and because of their anabolic effect on fibroblasts (Miller, 1996; Wouk et al., 1998).

The periods of time for the clinical and light microscopy studies were chosen in order to accompany the classical phases of healing repair in terms of exudation, proliferation and maturation (Slatter, 1990).

We used rabbits as experimental animals because they are easily obtained, managed and maintained and also because of their recognized value for research in comparative ophthalmology.

In the present study, chondroitin sulfate was used as proposed in the literature (Miller, 1996; Wouk et al., 1998) for the treatment of recurrent ulcerative keratitis of Boxer dogs and horses. The good results obtained by the cited investigators were not confirmed in the present study in which the alkali concentration used was $3 \mathrm{M}$.

Blepharospasm was significant during early periods in both groups. It is suggested that the phenomenon may have been due to the stimulation of nerve endings of the corneal epithelium and stroma and (Waring, 1984) and to reflex uveitis (Kern, 1990). Other investigators detected overt blepharospasm for at least two days after the beginning of treatment (Miller, 1996; Wouk et al., 1998) and stated that the anti-inflammatory action of the glycosaminoglycan probably reduced pain for periods longer than two days. The present results do not confirm the findings reported in the studies cited above since blepharospasm occurred at equal intensity and duration in Gll, which did not receive the glycosaminoglycan, compared to $\mathrm{Gl}$.

Moderate chemosis and intense conjunctival congestion occurred in both groups during the first days because of the direct action of the alkali on the conjunctival surfaces despite the immediate washing of the ocular surface after contact with the agent.

Ocular secretion of the mucoid type observed in both groups was due to the occurrence of damage to the lacrimal glands and ducts. Ocular lesions generated by chemical products can produce these lesions (Hughes, 1946; Christmas, 1991). Secretion was moderate 24 hours after injury and tended to disappear over subsequent time periods. Ocular secretion can also occur due to conjunctival inflammation, with stimulation of goblet cells (Gonçalves, 1975).

Corneal edema, which occurred indistinctly in the two groups, manifested in a manner similar to that observed in previous studies (Chung and Fagerholm, 1987), in which the authors reported recurrent episodes of endothelial barrier rupture with consequent corneal edema during the second week after alkali burn. Despite the similarity of the results, it should be pointed out that in the present study the edema reappeared late, by about the eighth week.
Edema was also correlated with dissociation of stromal collagen fibers (Girard, 1981; Waring, 1984) primarily generated by epithelial and endothelial dysfunctions (Vaughan and Asbury, 1977).

Dissociated collagen fibers and interlamellar edema together with endothelial destruction observed by light microscopy characterized corneal edema. Regression of the event, clinically starting after the first 10 days, coincided with the formation of the of a retrocorneal membrane acting as a barrier impermeable to aqueous humor. At 60 days, edema reappeared in an intense manner, coinciding with little endothelial cellularity during the period, as also reported by others (Matsuda and Smelser, 1973).

Newly formed vessels occurred 3 days after ulcer induction, originating from conjunctival and limbus areas on which sodium hydroxide had not been directly deposited, and later invading the cornea. The ischemic and necrotizing actions of the alkali on the sclera and conjunctiva prevented this occurrence in areas which received it directly, as previously shown in the literature (Christmas, 1991). Corneal neovascularizaion occurred in proportion to reepithelialization. Animals who suffered perforation of the cornea presented few newly formed vessels before the perforation. This finding confirms the importance of neovascularization in the process of corneal repair (Brown et al., 1969; Pfister and Burstein, 1976; Wagoner, 1997). Newly formed vessels were mainly located in the anterior third of the stroma, as previously reported in the literature (Hughes, 1946).

In the present study, a classical alkali-burn pattern was observed. Corneal opacification was basically due to the condensation or compaction of stromal fibers, as demonstrated by light microscopy. Sodium hydroxide, $3 \mathrm{M}$, caused corneal opacification of a porcelain-white color immediately after application to the cornea (Hughes, 1946). Cell lysis accompanied by collagen denaturation and hydrolysis of stromal glycosaminoglycans caused by the alkali (Pfister, 1983; Christmas, 1991) occurs by saponification of cell membrane lipids by hydroxyl through the reaction of the cation with the carboxylic groups of the glycosaminoglycans and collagen. These are the major elements involved in the pathogenesis of the lesions produced by alkaline substances (Wagoner, 1997).

Light microscopy showed PMN infiltration in the intact conjunctiva. The number of these cells was highest on the $10^{\text {th }}$ day, with the beginning of migration to the middle stroma, as previously shown by others (Hughes, 1946; Pfister and Burstein, 1976; Pfister, 1983; Burns et al., 1990). These cells are known to be the source of collagenolytic enzymes (Brown et al., 1970; Henriquez et al., 1976; Pfister and Burstein, 1976; Burns et al., 1989; Burns et al., 1990), which cause recurrence and, in some cases, perpetuation of the ulcers.

Microscopic examination also permitted the observation of cell debris in the anterior chamber from the $1^{\text {st }}$ to the $30^{\text {th }}$ day of evaluation. Previous studies (Hughes, 1946) have reported the occurrence of debris 2 hours after the injury.

The intraocular changes detected were due to the residual and penetrating action of alkali on the iris, ciliary body and crystalline, with consequent uveitis and cataract (Hughes, 
1946; Stein et al., 1973; Pfister, 1983; Christmas, 1991; Wagoner, 1997).

The evolution of the ulcers did not differ from that reported in the literature (Brown et al., 1969; Burns et al., 1990). The variable behavior in terms of the number and location of the ulcers agreed with data reported by other authors (Pfister and Burstein, 1976) who described the persistence of epithelial defects tending to progress to ulcers and perforations even after corneal reepithelialization. Other investigators (Brown et al., 1969) pointed out that the ulcers are the result of the action of collagenolytic enzymes produced and released at the site. Recurrent epithelial erosions were also reported in avascularized areas of severely burned corneas (Pfister, 1983). Melting and consequent perforations were observed in some corneas of $\mathrm{Gl}$ animals. We suppose that the $0.9 \%$ sodium chloride solution may have helped the cleansing of the ocular surface by acting as a diluent of the alkali residues.

\section{Conclusion}

There were no differences between the animals treated with a topical $5 \%$ chondroitin sulfate solution and the animals treated with $0.9 \%$ saline solution in terms of the evolution of corneas burned with $3 \mathrm{M}$ sodium hydroxide.

\section{Acknowledgments}

The authors would like to thank Fundação de Amparo à Pesquisa do Estado de São Paulo (FAPESP - grants 98/12801-6 and 98/ 03153-0) for financial support.

\section{References}

BROWN, S. I., WASSERMANN, H. E., DUNN, M. W. Alkali burns of the cornea. Archives of Ophthalmology, v. 82, p. 91-94, 1969.

BROWN, S. I., WELLER, C. A., AKIYA, S. Pathogenesis of ulcers of the alkali-burned cornea. Archives of Ophthalmology, v. 83, p. 205-208, 1970.

BURNS, F. R., GRAY, R. D., PATERSON, C. A. Inhibition of alkali-induced corneal ulceration and perforation by a thiol peptide. Investigative Ophthalmology and Visual Science, v. 31, p. 107-114, 1990.

BURNS, F. R., STACK, M. S., GRAY, R. D. et al. Inhibition of purified collagenase from alkali-burned rabbit corneas. Investigative Ophthalmology and Visual Science, v. 30, p. 1569-1575, 1989.

CHRISTMAS, R. Management of chemical burns of the canine cornea. Canine Veterinary Journal, v. 32, p. 608-612, 1991.

CHUNG, J. H, FAGERHOLM, P. Stromal reaction and repair after corneal alkali wound in the rabbit: a quantitative microradiographic study. EXperimental Eye Research, v. 45, p. 227-237, 1987.

CLEGG, P. D., JONES, M. D., CARTER, S. D. The effect of drugs commonly used in the treatment of equine articular disorders on the activity of equine matrix metalloproteinase-2 and 9 . Journal Veterinary Pharmacology Therapeutics, v. 21, p. 406-413, 1998.

DONZIS, P. B.; MONDINO, B. J. Diagnostic and surgical techniques. Survey of Ophthalmology, v. 32, p. 94-110, 1987.

GIRARD, L. J. Cornea surgery. In: GIRARD, L. J. Advanced techniques in ophthalmic microsurgery. St. Louis: CV Mosby Company, 1981. p. $2-26$.

GLADE, M. J. Polysulfated glycosaminoglycan accelerates net synthesis of collagen and glycosaminoglycans by arthritic equine cartilage tissues and chondrocytes. American Journal Veterinary Research, v. 51, p. 779-785, 1990.

GNÄDINGER, M. C., ITOI, M., SLANSKY, H. H. et al. The role of collagenase in the alkali-burned cornea. American Journal of Ophthalmology, v. 68, p. 478-483, 1969.

GONÇALVES, C. P.; Queratites. In: GONÇALVES, C. P. Oftalmologia. Brasilia: Atheneu, 1975. p. 131-140.

HENRIQUEZ, A. S.; PIHLAJA, D. J.; DOHLMAN, C. H. Surface ultrastructure in alkali-burned rabbit corneas. American Journal of Ophthalmology, v. 81, p. 324-331, 1976.

HUGHES, W. F. Alkali burns of the eye. I. Review of the literature and summary of present knowledge. Archives of Ophthalmology, v. 35, p. 423-449, 1946.
KERN, T. J. Ulcerative keratitis. Veterinary Clinics of North America Small Animal Practice; v. 20, p. 643-666, 1990.

MATSUDA, H.; SMELSER, G. K. Endothelial cells in alkali-burned corneas. Archives of Ophthalmology, v. 89, p. 402-409, 1973.

PFISTER, R. R.; BURSTEIN, N. The alkali burned cornea. I. Epithelial and stromal repair. Experimental Eye Research, v. 23, p. 519-535, 1976.

MILLER, W. W. Using polysulfated glycosaminoglycan to treat persistent corneal erosions in dogs. Veterinary medicine, v. 91, p. 916-922, 1996.

MORI, E. K.; BARROS, P. S. M.; TAKAHASHI, A. H. S. Fibronectina tópica no tratamento de úlcera de córnea de coelho após queimadura por álcali. Arquivo Brasileiro de Oftalmologia, v. 56, p. 254-257, 1993. PFISTER, R. R. The effects of chemical injury on the ocular surface. Ophthalmology, v. 9, p. 601-609, 1983.

SCHULTZ, G. S.; STRELOW, S., STERN, G. A. et al. Treatment of alkaliinjured rabbit corneas with a synthetic inhibitor of matrix metalloproteinases. Investigative Ophthalmology and Visual Science, v. 33, p. 3325-3331, 1992.

SLATTER, D. Cornea and sclera. In: SLATTER, D. Fundamentals of veterinary ophthalmology. 2. ed. Philadelphia:WB. Saunders, 1990. p. 257-303.

STEIN, M. R.; NAIDOFF, M. A.; DAWSON, C. R. Intraocular pressure response to experimental alkali burns. American Journal of Ophthalmology, v. 75. p. 99-109, 1973.

RASHMIR-RAVEN, A. M.; COYNE, C. P.; FENWICK, B. W. et al. Inhibition of equine complement activity by polysulfated glycosaminoglycans. American Journal Veterinary Research, v. 53, p. 87-90, 1992.

REBHUN, W. C. Bacterial ulcers of the equine cornea. Equine Practice, v. 3, p. 40-47, 1981.

VAUGHAN, D., ASBURY, T. Córnea e esclerótica. In: VAUGHAN, D. ASBURY, T. Oftalmologia geral. São Paulo: Universidade de São Paulo, 1977. p. 71-87.

WAGONER, M. D. Chemical injuries of the eye: current concepts in pathophisiology and therapy. Survey of Ophthalmology, v. 41, p.2 75313, 1997.

WARING, G. O. Corneal structure and pathophysiology. In: LEIBOWITZ $\mathrm{H}$. Corneal disorders: clinical diagnosis and management. Philadelphia: WB. Saunders, 1984. p. 3-25.

WOUK, A. F. P. F.; MICHELOTTO, P. V.; TIEPPO, T. et al. Polysulfated glycosaminoglycan used for the treatment of indolent corneal ulcers in equine patients. Rivista Societá Italiana Ippol., v. 4, p. 87-90, 1998. 